Article

\title{
The Psychomotor Profile of Pupils in Early Childhood Education
}

\author{
Alfonso Martínez-Moreno ${ }^{1, *} \mathbb{D}$, Susana Imbernón Giménez ${ }^{2}$ and Arturo Díaz Suárez ${ }^{1}$ \\ 1 Department of Physical Activity and Sports, University of Murcia, 30720 Santiago de la Ribera-San Javier, \\ Spain; ardiaz@um.es \\ 2 RESEARCH Group INGESPORTFI, University of Murcia, 30720 Santiago de la Ribera-San Javier, Spain; \\ s.imbernongimenez@um.es \\ * Correspondence: almamo@um.es
}

Received: 18 February 2020; Accepted: 20 March 2020; Published: 24 March 2020

check for updates

\begin{abstract}
The aim of the article was to find out the psychomotor profile of children in the second cycle of infant education (3-6 years) through an observational cohort study with a prospective character. A total of 277 students participated, $52.7 \%$ boys and $47.3 \%$ girls, grouped in a control group (52.3\%) and an experimental group (47.7\%). The McCarthy Scales of Aptitude (MCSA) and Psychomotor Skills for Children, 7 th edition, were used. The results showed that, in the global score and its dimensions, the time factor had significant and different influences, according to the control or experimental group. However, there were no significant differences in motor skills with respect to sex. As conclusions, the level of psychomotor development of the sample is close to the average of the development scale used. The time factor is significant when the subjects are subjected to stimulation; therefore, this must be taken into account in any therapeutic or learning process.
\end{abstract}

Keywords: child development; motor skill; preschool education; educational measurement

\section{Introduction}

The study of childhood psychomotor skills began with the intention of getting to know children better and being able to analyze and create tools that would help assess the motor status of these subjects [1].

There are several theories that underpin psychomotricity and psychoanalysis, the latter from the libidinal character as well as in that of language. Movement and body are very important in these theories because they are of significant relevance to the child's affective development [2]. Psychopedagogical theory emphasizes the relationship of psychomotor development with academic performance. According to [3], having a well-integrated body scheme is necessary for (i) the perception and control of one's body, (ii) an economic postural balance, (iii) a well-defined laterality, (iv) the independence of the segments in relation to the trunk and the independence of segments between them, and (v) the control and balance of pulsations or inhibitions closely associated with body scheme and breath control. Another current also influential in this psychopedagogical perspective of psychomotor skills is physical education. According to [4], it uses human movement in all its forms as a pedagogical medium of education, and there are three stages in the development of the body scheme: 1 . the stage of the body lived (up to three years); 2 . the perceptual discrimination stage (three to seven years); 3 . the stage of the represented body (seven to twelve years). Neuropsychiatric psychomotricity binds the parts of evolutionary, psychoanalytic, and pedagogical psychomotricity. Having a proper use and integration of the body scheme positively helps the subject adapt in space and time [5]. The tone and the motor action then have a motor function and a regulatory affective function of emotions. 


\section{Psychomotricity in Early Childhood Education}

It is in early childhood that wellbeing in the child population must be ensured, as it is at these ages that there is greater vulnerability to disadvantages and at the same time greater potential for long-term benefits [6]. At the stage of three to five years, which coincides with the second cycle of early childhood education in Spain, at the psychomotor level there is progress in the maturation of the muscle system, nervous, and bone structure of children [7]. It is a stage in which the structures of the person related to the anatomical and the physiological develop, in addition to the affective and intellectual—structures that develop at the top, as together they form a unit. In order to achieve comprehensive training in the child, it is essential not to avoid psychomotor work, especially in classes of early childhood education, which takes into account both aspects, the anatomical-physiological and the affective-intellectual [8-10]. According to [11], psychomotricity specifies the considerations that render the body in a given subject as a means of relationships and expression. According to [12], "Motority without cognition is possible, but cognition without motor skills is not." Focusing on body language, the central core of psychomotor skills, and the axis of research, body image is the representation of the body that each individual builds in his mind [13]. According to [14], psychomotor development refers to the interrelationship of internal and external factors, as well as the process of maturation of the central nervous system. The development of cognition and personality is indispensable, because it is at this stage-which coincides with the second cycle of early childhood education-that the necessary aspects in personal and social development are settled. In addition, learning that forms the basis for achieving basic skills is internalized. From the beginning of psychomotority, the importance of psychomotor development and the involvement it has in cognitive, affective, and personal areas [3,4,15-20] is evident.

In direct relation to learning, in [21], the author advocated psychomotor skills as a line of work in the hands of teachers, for whom the goal is to facilitate the learning of students and the development of their personality. According to [22], there is a positive correlation between fine psychomotricity and writing development, and the psychomotor dimensions of manual viso coordination, facial mobility, and phonetic and gestural dimensions influence the syllabic and syllabic-alphabetic dimensions, and vice versa. A child's body is used as a media element for learning the alphabet, and the letters are graphed with their own body [23]. A girl with Prader Willi syndrome, after multidisciplinary intervention with psychomotor stimulation, made significant improvements, which shows the need to incorporate psychomotricity into multidisciplinary teams [24]. Also [25], they demonstrated the effectiveness of a psychomotor program for postural balance with children with cortical cerebral palsy with motor development level. Similarly, in [26], it was found that a psychomotor intervention programme improved adaptation to the environment and the abilities of children with disabilities. On the other hand, in [27], the author found beneficial and positive relational differences between experiential psychomotor and oral language development. From a disciplinary perspective, in [28], the authors argue that the various professionals involved in child care from the educational and health fields can speak a common language, assuming that the brain is the regulatory body of all the processes of human beings, and that should not be excluded in any interpretation of behavioral phenomena (p. 10).

Detecting difficulties or disorders in motor development early affords us an opportunity for early intervention and timely treatment that allows us to correct or at least mitigate other alterations, for the benefit not only of the subject but also of the family and of society [29]. Assessment of the health status of minors using standardized tests has been recommended [30]. Both tests and questionnaires have been shown to be effective in specifying the level of maturity of children [31-35]. In line with this, in [36], the authors argue that evaluation allows and provides essential information about the subject evaluated. It is a tool that guides professionals and teachers in the therapeutic or teaching process. The evaluation methods are varied and include three types of actions: screening, monitoring, and evaluation [37]. The latter is the priority in this work.

Early care services in health partners have recognized the need to include psychomotor developmental stimulation programmes in people who are affected with or at risk of developmental 
disorders [38]. This is because, for a few years now, psychomotor interventions have been present for autistic children [39].

Research is multidisciplinary because, although psychomotricity today is a known discipline, the practical knowledge that is held of the true psychomotor profile of children aged three to five years is not subject to the standards of development scales and testing. However, in [40], it is argued that a certain level of psychomotor skills is sufficient for children and that they therefore receive adequate stimulation according to their age. It would be interesting to outline an irrefutable psychomotor profile in a natural context such as school.

\section{Materials and Methods}

\subsection{Procedure}

This research deals with a prospective observational cohort study with a homogeneous non-probabilistic sample of informal selection. The students belong to a concerted teaching school in the Region of Murcia, Spain. For the recruitment of minors, the project center management was informed. Subsequently, in a talk to the parents, the objectives, methodology, etc. of the project were explained. Those who declined to participate were excluded, and those who accepted signed corresponding informed consent documents. The criteria of the Ethics Committee of the University of Murcia were followed. The research was organized in three phases: 1 . pretest-sample evaluation through questionnaires and motor tests; 2. psychomotor stimulation-two groups created: one control, receiving normal psychomotor classes, and one experimental group, receiving, in addition to their psychomotor classes, two more weekly sessions of psychomotor stimulation for 6 weeks, i.e., 12 more sessions; 3 . posttest-evaluation of the sample through questionnaires and motor tests, identical to those of Phase 1.

The program developed by the experimental group followed the evolutionary characteristics of the participants in the psychomotor area and the objectives of psychomotor practice according to the overall development in which they were located. The activities worked on the following psychomotor aspects: knowledge of the body scheme, laterality, coarse general coordination, manual oculus coordination, balance, rhythm, and arm coordination. This was supported with attractive materials and objects, as well as motor circuits and motor stories.

\subsection{Participants}

The study consists of 277 students from the second grade of early childhood education, of whom $52.7 \%(146)$ are boys and $47.3 \%$ (131) are girls. The sample is divided into a control group (GC) $52.3 \%$ $(n=145)$ and an experimental group (GE) $47.7 \%(n=132)$. Of the total sample, $30.4 \%$ (No. 85) were in 1 st grade aged between 34 and 47 months at the start of the research, and 40-53 months at the end, $39.9 \%$ (No. 110) were 2nd grade with ages 45-59 months at baseline and 51-65 months at the end, and $29.7 \%$ (No. 82) were in 3rd grade, with ages 57-71 months at the beginning and 63-77 at the end.

\subsection{Instrument}

The McCarthy Scales of Skills and Psychomotor Skills for Children (MSCA) 7th edition were used [41]. The psychometric rigor of the scale is in the General Cognitive Index, with an average reliability coefficient of 0.93 , varying in the other scales between 0.79 and 0.88 . With regard to stability, reliability coefficients range from 0.75 to 0.90 . Its validity is demonstrated in [42]. These scales contain 18 independent tests that evaluate the subject's aptitudinal variables, mainly aimed at determining their overall intellectual level and their strengths and weaknesses in the most important aptitudinal variables. The tests were grouped into six scales, but only motor skills were used in this study. Five tests were conducted: (i) Leg coordination-Test No. 9. For each of the test elements, there are two attempts. Data from the highest score of the two attempts are taken. There are 6 elements in total, and Elements $1-5$ are scored from 0 to 2 , and Element 6 from 0 to 3 . The test application is terminated if the 
two attempts in Item 5 fail. (ii) Coordination of arms-Test No. 10. Organized in 3 parts, they all start with Part 1: throw a mini-basketball. This is scored from 0 to 7 points [p] according to the number of boats [b] (0p x 0b; 1p-1b; 2p-2b; 3p-3-5b; 4p-6-8b; 5p-9-11b; 6p-12-14b; 7p-15b). There are two attempts, and the highest of the two attempts is taken as the final score. Part 2 follows. Subjects catch the bag with both hands first, then with their preferred hand, and then with the other hand. One has three attempts. Each test is scored from 0 to 1 . The test ends if it fails in Element 1. Part 3 has two elements: target shooting, first with the preferred hand and then with the other hand. Subjects are given a score from 0 to 2 for each attempt. Part 3 applies to everyone. At all times, one is informed that they have 3 opportunities in case they do not achieve the maximum score on the first]. (iii) Imitative action-Test No. 11. This test consists of 4 elements with a rating from 0 to 1 . Its maximum score is 4 . (iv) Copying of drawings-Test No. 12. All subjects start with Element 1. Elements between 1 and 3 score from 0 to 1 . For Items 4 and 5 , the score is from 0 to 2 . For Items $6,7,8$, and 9 , the score is from 0 to 3 . The test ends after 3 consecutive failures. It has a maximum score of 19. (v) Drawing a child-Test No. 13. This test only applies if the subject scores 1 on the drawing copy test. The child should only draw the figure of a child. It is scored from 0 to 2, according to the appearance, accuracy, and placement of the segments of the body such as the head, hair, eyes, nose, mouth, neck, trunk, arms and hands, and legs and feet. The maximum score is 20. The leg coordination (CPP), arm coordination (CBBB), and imitative action (AI) tests measure gross motor skills (MG), and copying of drawings (CD) and drawing of a child (DN) tests measure fine motor skills (MF). One obtains a direct score (PD) that determines the psychomotor percentile, which could be a low ( $<22$ points), medium (50), or high $(>78)$ risk index.

\subsection{Statistical Analysis}

For qualitative variables (sample subjects and gender and age characteristics), the number of cases in each category and their corresponding percentage is obtained; for quantitative variables (psychomotor skills), minimum, maximum, mean, and standard deviation values are obtained. The comparison between groups for the analysis of qualitative variables was performed via the chi-square test. For the comparison of means between two groups, the t-Student test was used once assumptions of normality were checked with the Kolmogorov-Smirnov test and once assumptions of variance in homogeneity were checked with the Levene test. To contrast whether the change between the scale measurements was significant, ANOVA analyses of partially repeated measures were performed through the General Linear Model (MLG) procedure to study the effect of intra-subject (time) and inter-subject (group) and their interaction on dependent variables (scales).

\section{Results}

As for demographic variables relative to GC and GE, Table 1, the results showed that there are no significant differences between the two. There are also no significant differences in the initial scores between them on any of the scales. To ensure the absence of bias in the formation of groups, the groups are homogeneous with respect to these variables.

With regard to the results derived from the comparison between MF and MG by sex, it should be noted that there are no statistically significant differences, in any of the areas of MF, MG, and OE. Two groups were established in each of the grades-1st, 2nd, 3rd-of Early Childhood Education, according to date of birth: Group 1 (G1), children born in the second semester of the year, and Group 2 (G2), children born in the first half of the year.

Based on comparison of the results of the pretest according to age in the three grades, there are statistically significant differences between G1 and G2, G1 always being lower compared to G2. First grade results are as follows: $\mathrm{MF}(p=0.03), \mathrm{DP}(p=0.036), \mathrm{CD}(p=0.037), \mathrm{MG}(p=0.032), \mathrm{AI}(p=0.018)$, and $\operatorname{PD}(p=0.012)$. Second grade results are as follows: $\mathrm{DN}(p=0.018), \operatorname{MG}(p=0.029), \operatorname{CBB}(p=0.035)$, $\mathrm{OE}(p=0.006)$, and $\mathrm{PD}(p=0.04)$. Third grade results are as follows: $\mathrm{DN}(p=0.011), \mathrm{CD}(p=0.001)$, 
MG $(p=0.001), \operatorname{CBB}(p=0.057)$, and OE $(p<0.001)$. As for SCALE DP in the GC and GE pretests, there are no significant differences.

Results of intra-subject factor analyses for the scores obtained in MF and its dimensions show that, in both the overall score and each of its dimensions, the time effect was statistically significant, indicating that the scores changed significantly between assessments, regardless of the group. However, there was a significant effect of group and time interaction, which reveals that the passage of time influenced students differently, depending on the group (Figure 1). The GC improves on the MF and its components, $\mathrm{CD}$ and $\mathrm{DN}$, although not considerably. However, the GC improves significantly in $\operatorname{MF}(p<0.001), \mathrm{CD}(p<0.001)$, and DN $(p=0.001)$.
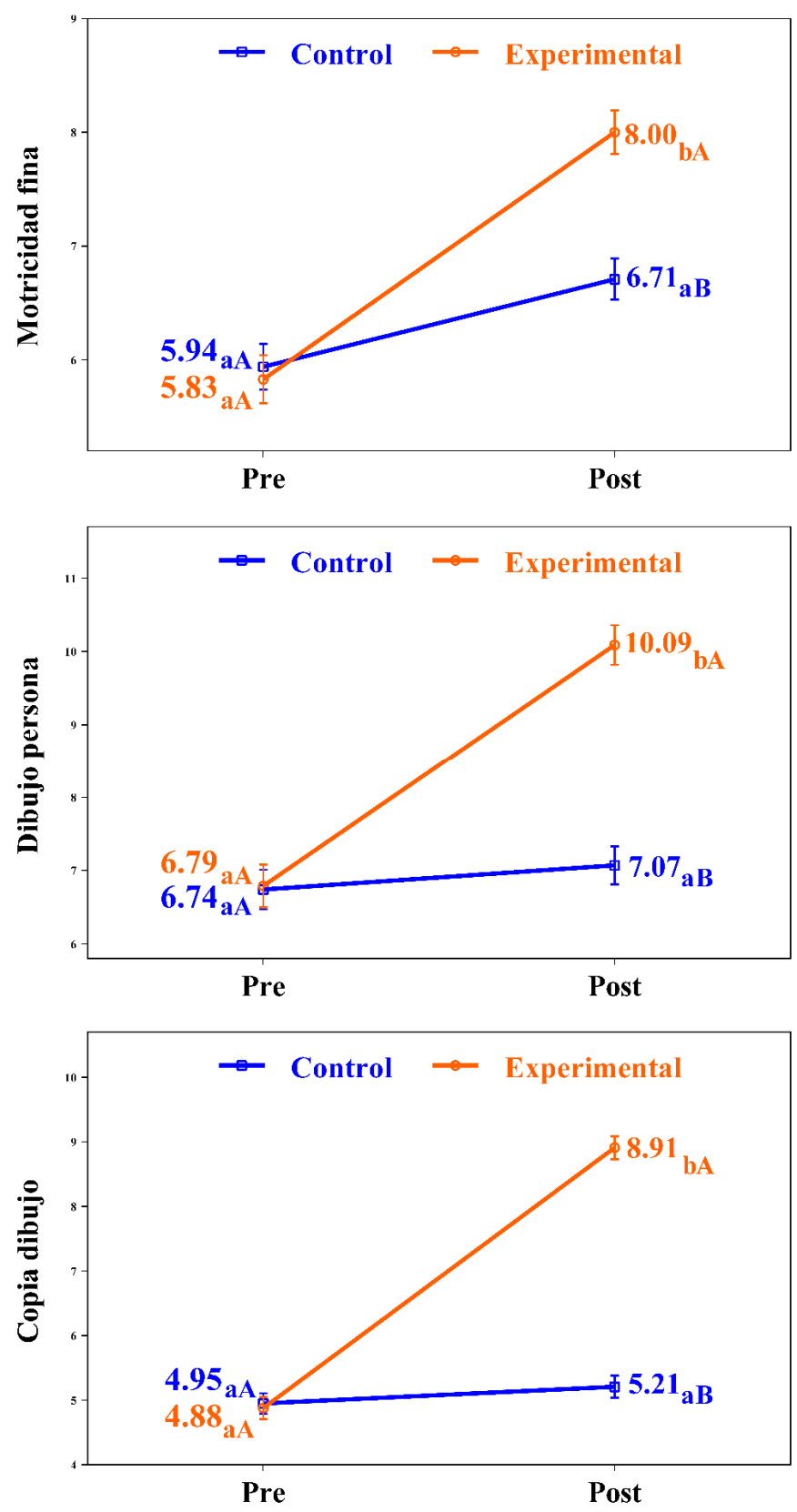

Figure 1. Group and time interaction in fine motor skills and dimensions. a-b: Comparisons between time moments in the same group. Different lowercase letters indicate statistically significant differences (Bonferroni correction). A-B: Comparisons between groups at the same time. Different uppercase letters indicate statistically significant differences (Bonferroni correction). 
Table 1. Descriptive and comparative demographic variables by group.

\begin{tabular}{|c|c|c|c|c|}
\hline & \multicolumn{2}{|c|}{ Group } & \multirow{2}{*}{ Test } & \multirow{2}{*}{$p$-Value } \\
\hline & Experimental & Control & & \\
\hline Age (months), average (DT) & $106.37(6.96)$ & $105.32(7.05)$ & $\mathrm{T}(275)-1242$ & 0.215 \\
\hline Sex, $\mathrm{n}(\%)$ & & & $2(1)-0.742$ & 0.389 \\
\hline Child & $66(45.2)$ & $80(54.8)$ & & \\
\hline Girl & $66(50.4)$ & $65(49.6)$ & & \\
\hline Course, n (\%) & & & $2(2)-1074$ & 0.584 \\
\hline 1st & $42(50.0)$ & $42(50.0)$ & & \\
\hline 2nd & $48(43.6)$ & $62(56.4)$ & & \\
\hline 3rd & $41(50.0)$ & $41(50.0)$ & & \\
\hline Size, Medium (DT) & $17.70(3.64)$ & $17.59(3.80)$ & $\mathrm{t}(275) \times 0.232$ & 0.817 \\
\hline Weight, average (DT) & $51.98(10.17)$ & $51.68(9.57)$ & $\mathrm{t}(275) \times 0.254$ & 0.8 \\
\hline BMI, medium (DT) & $15.56(2.13)$ & $15.75(2.12)$ & $t(275)-0.734$ & 0.463 \\
\hline
\end{tabular}

In terms of spatial orientation (OE), the time effect proved statistically significant between pretest and posttest, regardless of group. The passage of time influenced the groups differently (Figure 2). The GC shows a slight increase in score without significant differences, as a result of each subject's own maturing process, while in the GE there was a statistically significant increase in posttest with respect to scores in the pretest.

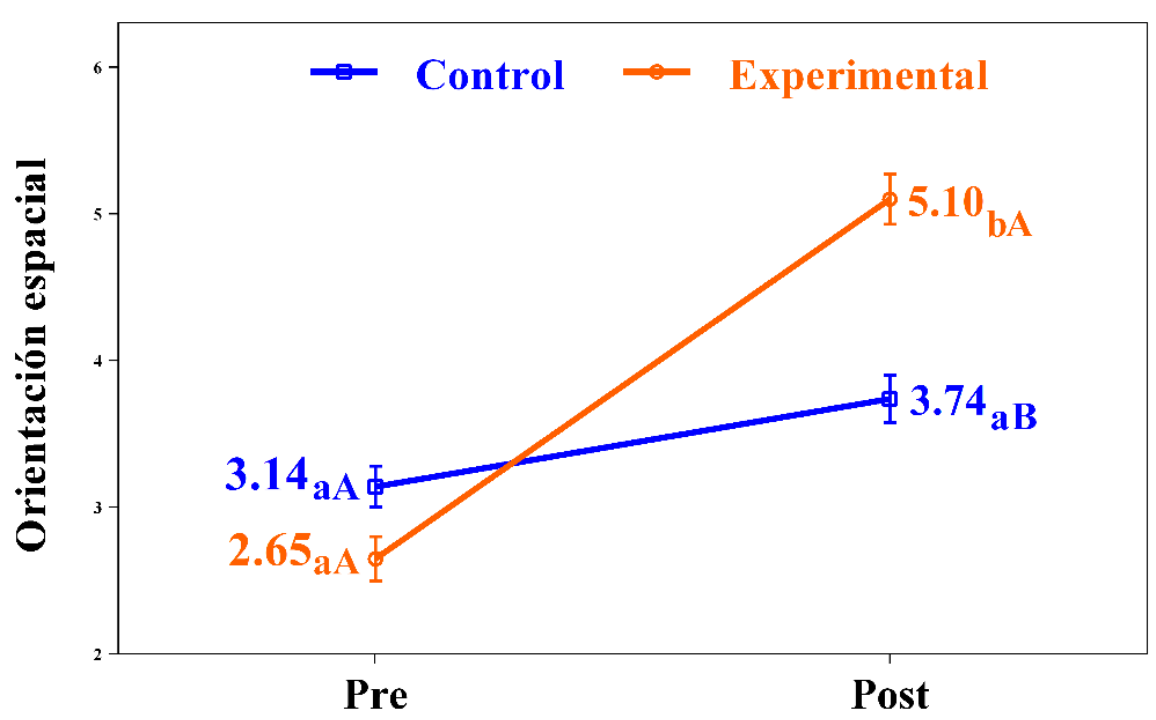

Figure 2. Group and time interaction in spatial orientation. a-b: Comparisons between time moments in the same group. Different lowercase letters indicate statistically significant differences (Bonferroni correction). A-B: Comparisons between groups at the same time. Different uppercase letters indicate statistically significant differences (Bonferroni correction).

In relation to time and MG $(p=0.002)$, the results showed a statistically significant increase, while the interaction of time and group factors was not significant. As for CBB $(p=0.003)$, CPP $(p<0.001)$, and $\mathrm{AI}(p<0.001)$, the time effect was also statistically significant, indicating that scores varied between evaluations, regardless of group. However, there was a significant effect of group and time interaction, which shows us that the passage of time influenced the sample differently, depending on the group (Figure 3). The evolution in MG was similar in both groups, where there are hardly any differences. However, in its dimensions, in CBB $(p=0.002)$, CPP $(p=0.005)$, and AI $(p=0.009)$, the improvement of GE is significantly higher than that of GC. 

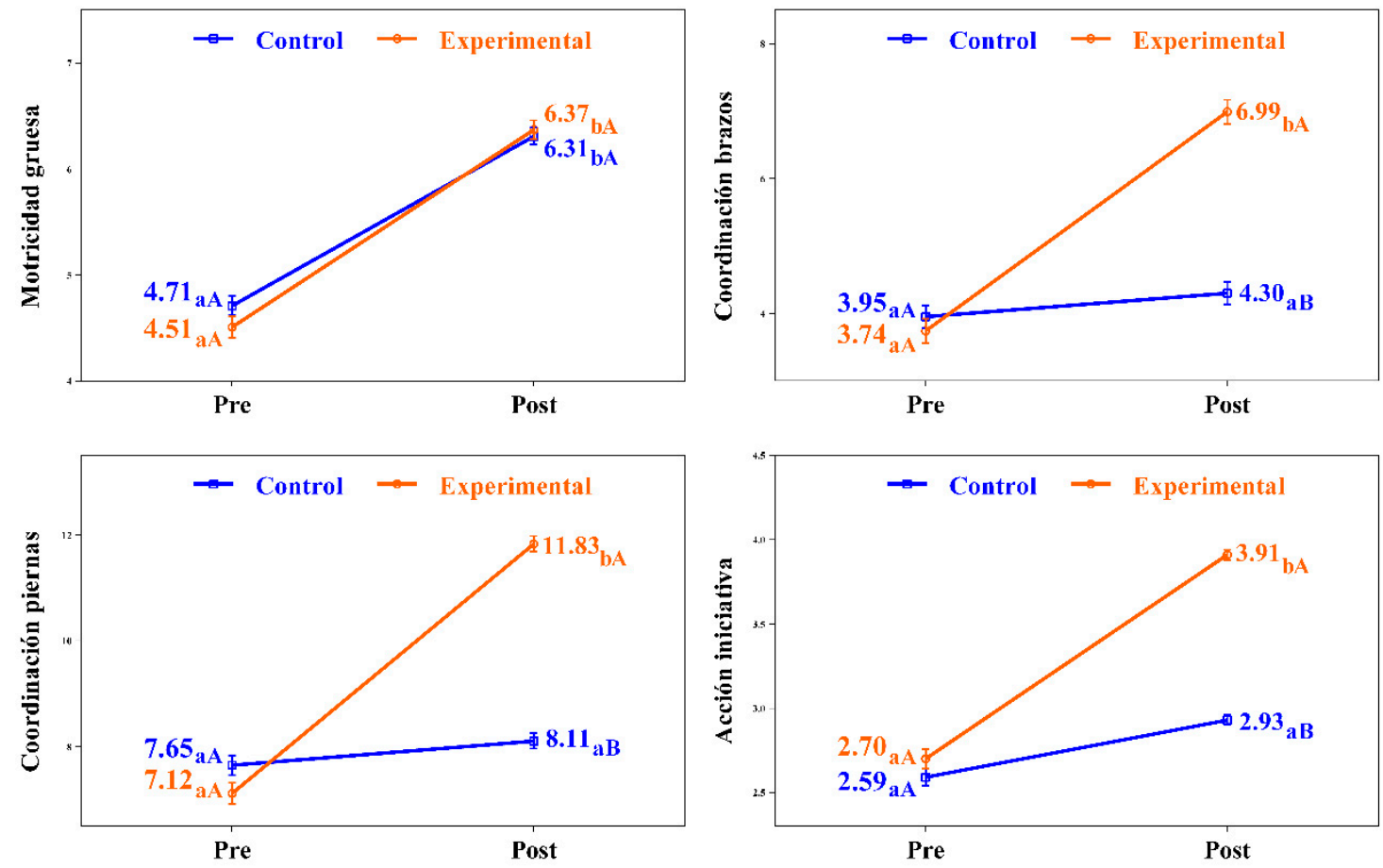

Figure 3. Group and time interaction in gross motor skills and their dimensions. a-b: Comparisons between time moments in the same group. Different lowercase letters indicate statistically significant differences (Bonferroni correction). A-B: Comparisons between groups at the same time. Different uppercase letters indicate statistically significant differences (Bonferroni correction).

The average PD results are 44.39 points for the GE and 45.63 for the GC. The psychomotor development of the sample of students aged 3 to 5 years is close to the mean parameters of the scale of development used. Only nine subjects presented in the pretest a PD $<22$, which could indicate deficit or risk in their development. Of the nine, six were part of the experimental group, so they participated in the stimulation program. In the posttest of nine that scored typical very low scores, seven improved by obtaining percentiles that approached the average. Of the seven who improved, six participated in the stimulation program. A GC child naturally improved his psychomotor profile, and only one GE child made no improvement. This determines that the results of the development scales used are positively close to the mean.

\section{Discussion}

The results obtained in the pretest are shown as indicated in the evaluation test manual used in the research, the McCarthy MSCA scale, which is more demanding in tests of some dimensions than the others, in the sample under study.

The results obtained by comparing GE and GC indicate that there is homogeneity in the 1st, 2nd, and 3rd groups of infants. This homogeneity has made it possible for the development of psychomotor skills to make uneven progress throughout the sample regardless of whether or not stimulation is undergone, which reflects improvement by intrinsic maturation over time.

Regarding sex, we did not notice any differences in terms of the sample under study in the dimensions of MG and MF psychomotor skills, unlike Tierney, Smith, Axworthy, and Radeliffe [43], and Campos de Sousa [44].

In the CBB pretest, 3.85 points, the children from the sample showed worse results compared to the CPP pretest, 7.39 points. The the GE posttest showed on average 6.90 points, and the GC posttest showed 4.30, coinciding with Delgado-Lobete and Montes-Montes [45], who also showed that older 
children have better psychomotor development not only because their nervous system has matured longer but because they have had more opportunities for motor experience.

Depending on the age, G2 students differ in their G1 motor skills, similar to the findings of Cecchini et al. [46], who found age differences in schoolchildren ages 3 to 12 in the nine motor skills assessed, with the oldest being significantly higher. We are also consistent with Lesma, Pérez-González, and Salinero [47], who showed that those born in the early year had a greater development of their motor skills and were signed by professional football teams in a higher percentage.

GE and GC improve in motor skills, going from direct overall scores in psychomotor skills from 28.16 to 35.93 in GE and from 28.91 to 34.49 in GC, both improving over time, regardless of the methodology used in the sessions, coinciding with Noguera et al. [48] and Vega [49]. However, our results differ from those of Ferry-Rey, Dueñas, and Camps [50], who obtained improvements in psychomotority when it was practiced dynamically, and those of Terry [51], who found improvements in 3-year-olds when they worked from a normative methodology. In contrast to this, Mendieta, Gayrey, Valcerde, and Vargas [52] showed how children also improve their psychomotor profile by playing scratch due to the static and dynamic balancing activities such as walking, running, and jumping exercises that this game involves.

The average results of the scores, according to the scale baremation used for this purpose, the MSCA, the minors of the sample showed an M of 50, corroborating previous studies by Delgado-Lobete and Montes-Montes [45]. Accurate knowledge of the psychomotor level would help teachers more accurately detect possible day-to-day deviations from mean values. Necessary actions could be taken to mitigate these potential lags in early stages, with a greater chance of success in mitigating or eliminating deficits.

\section{Conclusions}

It is possible to determine the current psychomotor development of children from 3 to 5 years, under the 2nd grade of childhood education, by means of a psychomotor evaluation using evaluation tools. The information provided by the psychomotor evaluation scales is relevant and significant in order to establish work plans that improve the skills of the students under study.

There are no significant differences in boys' motor skills compared to those of girls. Obtaining similar values both at the level of spatial orientation and in terms of fine and/or coarse motor skills, indicating that there are no differences in the psychomotor profile according to sex.

Children born in the first semester have a better overall psychomotor profile compared to those born in the second. Those born in the second semester show poorer results in some of the motor skills compared to those born in the first semester.

The time factor is significant when children are stimulated, with noticeable improvements in their motor skills, thus benefiting the original maturation process. The time factor should be taken into account in any therapeutic or learning process. However, it is clear that, if there is greater stimulation, the benefits are exponentially greater.

The children in the sample achieved middle developmental percentiles in their overall psychomotor skills on the MSCA scale. Children with a low psychomotor profile, after undergoing a stimulation program, improved by performing near the average in their overall motor skills.

The information provided by the developmental scales detailing the psychomotor profile according to age in months should continue to discriminate differences in months in motor development items, for children aged from 3 to 5 years, and not only on an annual basis. This will more accurately capture the specific goals that a child of this age must achieve.

The information provided is relevant to facilitate a work plan for teachers that helps estimate areas of improvement in the motor development of minors, which can result in important pedagogical and/or therapeutic contributions.

Precocity in problem detection is potentially positive in order to eliminate or mitigate them. Therefore, children's education teachers should be aware of the wealth and benefits that psychomotor 
skills bring in the development of other fields that help develop complete people in all their dimensions. Teachers at this educational stage should determine and implement psychomotor skills, not as a second-order area, but as a first-order area, which is the basis on which other progress, necessary for the full development of the person, is based.

We must understand that all maturation processes are not equal in all children. Each child evolves at a different rate, which is why, although the results have shown improvement in the overall direct scores of motor skills, the scores typified in some cases have been reduced. For future research, longitudinal studies should be carried out, leaving the data recorded in their respective files, so that the evolution can be analyzed. It is also important to be able to carry out a post-test to determine if the effects of the intervention last over the long term, extending the sample to other contexts, including geographical contexts. This study has shown how psychomotor skills are an aspect of human development that can improve when it is continuously worked on and that it benefits the development of minors. It is advisable for students to perform $4-5$ sessions a week.

Author Contributions: Conceptualization: S.I.G. and A.M.-M.; methodology: A.D.S.; validation: S.I.G. and A.M.-M.; formal analysis: A.D.S.; research: S.I.G.; resources: S.I.G. and A.D.S.; data curation: S.I.G.; writing —original draft preparation: A.M.-M.; writing—revision and editing: S.I.G. and A.M.-M.; visualization: A.D.S.; monitoring: A.M.-M.; project management: A.M.-M. All authors have read and agreed to the published version of the manuscript.

Funding: This research received no external funding.

Conflicts of Interest: The authors declare that there is no conflict of interest.

\section{References}

1. Monge, M.Á.; Meneses, M. Instrumentos de evaluación del desarrollo motor. Rev. Educ. 2002, 26, 155-168.

2. Gessell, A. El Infante y el Niño En La Cultura Actual; Paidós: Buenos Aires, Argentina, 1979.

3. Picq, L.; Vayer, P. Educación Psicomotriz y Retraso Mental; Científico-Médico: Barcelona, España, 1969.

4. Le Boulch, J. Desarrollo Psicomotriz Desde el Nacimiento Hasta Los 6 Años. Practica de la Psicomotricidad en la Escuela Preescolar: Consecuencias Educativas; Paidós: Buenos Aires, Argentina, 1962.

5. Defontaine, J. Manual de Reeducación Psicomotriz. Diploma de Psicoreeducador del Estado Francés; Médico y Técnica: Barcelona, España, 1978.

6. Minujín, A.; Bagnoli, V.; Osorio, A.M.; Aguado, L.F. Primera Infancia Cómo Vamos: Identificando Desigualdades Para Impulsar la Equidad en la Infancia Colombiana; Sello Editorial Javeriano: Santiago de Cali, Colombia, 2015.

7. Cañizares, J.M.; Carbonero, C. El Crecimiento y el Desarrollo Neuromotor, Óseo y Muscular en la Edad Escolar; Wanceulen: Sevilla, España, 2016.

8. Lagrange, G. Educación Psicomotriz. Guía Práctica Para Niños de 4 a 14 Años. Educación Didáctica; Martínez Roca: Madrid, España, 1986.

9. Mora, J.; Palacios, J. Desarrollo Físico y Psicomotor a lo Largo de los Años Preescolares. Psicología del Desarrollo; Félix Valera: La Habana, Cuba, 1991.

10. Comellas, M.J.; Perpinyà, A. Psicomotricidad en la Educación Infantil. Recursos Pedagógicos; CEAC: Barcelona, España, 2003.

11. Cipollone, M.D. La dislexia, desde el cuerpo. Revista Iberoamericana Psicomotricidad Técnicas Corporales 2018, 43, 126-137.

12. Da Fonseca, V. Ontogénesis de la Motricidad: Estudio Psicobiológico del Desarrollo Humano; G. Núñez Editor: Madrid, España, 1988.

13. Rodríguez-Camacho, D.F.; Alvis-Gomez, K.M. Generalidades de la imagen corporal y sus implicaciones en el deporte. Rev. Fac. Med. 2015, 63, 279-287. [CrossRef]

14. Cobos, P. El Desarrollo Psicomotor y Sus Alteraciones: Manual Práctico Para Evaluarlo y Favorecerlo; Pirámide: Madrid, España, 2007.

15. Ajuriaguerra, J. Manual de Psiquiatría Infantil; Massón: Barcelona, España, 1983.

16. Aucoutier, B.; Lapierre, A. La Educación Psicomotriz Como Terapia, "Bruno"; La Médica y técnica: La Habana, Cuba, 1985.

17. Berruezo, P.P. El cuerpo, el desarrollo y la Psicomotricidad. Psicomotricidad Rev. Estud. Exp. 1995, 49, $15-26$. 
18. Gessell, A. Diagnostico del Desarrollo Normal y Anormal del Niño; Paidos: Buenos Aires, Argentina, 1981.

19. Piaget, J. El Nacimiento de la Inteligencia en el Niño; Aguilar: Madrid, España, 1969.

20. Wallon, H. La Evolución Psicológica del Niño; Critica: Barcelona, España, 2000.

21. Berruezo, P.P. Hacia un marco conceptual de la Psicomotricidad a partir del desarrollo de su práctica en Europa y en España. Rev. Int. Form. Prof. 2000, 37, 21-33.

22. Arrese, H. La Psicomotricidad Fina y el Desarrollo de la Escritura en Los Estudiantes de Cinco Años de Educación Infantil. Ph.D. Thesis, Universidad Cesar Vallejo, Chiclayo, Perú, 2019.

23. Bolaños-Motta, J.I.; Pérez-Rodríguez, M.A.; Casallas-Forero, E. Alfabetización Corporal. Una propuesta de aula desde la psicomotricidad. Estudios Pedagógicos 2018, 44, 23-34. [CrossRef]

24. Bustos, E.; Castellani, M.N. Una mirada desde la complejidad de una niña, el aporte psicomotriz en la interdisciplinariedad. Un caso clínico: "Agustina". Revista Iberoamericana Psicomotricidad Técnicas Corporales 2018, 43, 97-110.

25. Aguilar-Alaníz, M.L.; Rolón-Lacarriere, O.G.; Cervantes, A. Effectiveness of the program to psychomotor postural equilibrium in spastic hemiparesis children with level of motor cortical development in children's. Rev. Mex. Neuroc. Mex. 2010, 11, 269-278.

26. Herón-Flores, M.; Gil-Madrona, P.; Sáez-Sánchez, M.B. Contribución de la terapia psicomotriz al progreso de niños con discapacidades. Rev. Fac. Med. 2018, 66, 75-81. [CrossRef]

27. Brigada, A.C. Psicomotricidad Vivencial y Lenguaje Oral en Niños de Cinco Años de Una Institución Educativa Publica de Ventanilla-Callao. Ph.D. Thesis, Universidad San Ignacio de Loyola, Lima, Perú, 2019.

28. Portellano, J.A.; Martínez-Arias, R.; Zumarraga, L. ENFEN, Evaluación Neuropsicológica de Las Funciones Ejecutivas en Niños; TEA: Madrid, España, 2009.

29. Schonhaut, L.; Álvarez, J.; Salinas, P. El pediatra y la evaluación del desarrollo psicomotor. Rev. Chilena Pediatr. 2008, 79, 26-31. [CrossRef]

30. Asociacion Americana de Pediatría. Available online: https://www.healthychildren.org (accessed on 16 December 2019).

31. Flamant, C.; Branger, B. Parent completed development screening in prematura children: A valid tool for follow up programs. PLoS ONE 2011, 6, e20004. [CrossRef]

32. Limbos, M.M.; Joyce, D.P. Comparison of the ASQ and PEDS in screening for developmental delay in children presenting for primary care. J. Dev. Behav. Pediatr. 2011, 32, 499-511. [CrossRef] [PubMed]

33. Schonhaut, L.; Salinas, P.; Armijo, I.; Schönstedt, M.; Álvarez, J.; Manríquez, M. Validación de un cuestionario Administrado para Evaluación del desarrollo Psicomotor. Rev. Chilena Pediatr. 2009, 80, 513-519. [CrossRef]

34. Schonhaut, L. Evaluación del desarrollo Psicomotor en las consultas pediátricas. Experiencia en clínica alemana. Rev. Contacto Cient. 2010, 31, 455-466.

35. Schonhaut, L.; Armijo, I. Aplicabilidad del Ages y Stages Questionnaires para el tamizaje del desarrollo psicomotor. Rev. Chilena Pediatr. 2014, 85, 12-21. [CrossRef]

36. Aliaga, L.; Figueroa, T. Educación: Pilar fundamental de la educación. Revista Educrea 2018, 1, 1-2.

37. Vericat, A.; Orden, A.B. Herramientas de Screening del Desarrollo Psicomotor en Latinoamérica. Rev. Chilena Pediátr. 2010, 81, 391-401. [CrossRef]

38. Ley Orgánica 39/2006, de 14 de Diciembre de Promoción de Autonomia Personal y Atención a Las Personas en Situación de Dependencia; BOE num.299; Boletin Oficial del Estado: Madrid, Spain, 2006; pp. 44142-44156.

39. Rabadán, M.; Serranoba, J. El abordaje psicomotriz en niños con autismo. Rev. Eipea 2017, 2, 1-14.

40. Chipana, A.R.; Ordoñez, C.M. Nivel de Psicomotricidad de Los Niños y Niñas de Cinco Años de la I.E.I "Ana Mogas" Quillasu-Oxapampa. Ph.D. Thesis, Universidad Nacional de Daniel Alcides Carrión, Cerro de Pasco, Perú, 2019.

41. McCathy, D. Escalas McCarthy de Aptitudes y Psicomotricidad Para Niños; Pearson SA: Madrid, España, 2011.

42. Santana, A.C.; Rojas, M.; Pacheco, J.S. McCarthy scales of skills and psychomotor skills for children. Adv. Meas. 2006, 4, 148-149.

43. Tierney, L.; Smith, L.; Axworthy, D.G.; Radeliffe, S.G. The Mc Carthy Scales of childrens Abiloties sex and handedsness effects in 128 scotish five years old. Br. J. Educ. Psychol. 1984, 54, 101-105. [CrossRef]

44. Campos de Sousa, D. Psychopedagogical proposal to develop psychomotor skills in children of early childhood education. Ibero Am. J. Psychomot. Body Tech. 2003, 12, 61-82.

45. Delgado-Lobete, L.; Montes, R. Perfil y desarrollo psicomotor de los niños españoles de 3 a 6 años. Sport. Rev. Técn. Cient. Deport. Esc. Educ. Fís. Psicomot. 2017, 3, 454-470. [CrossRef] 
46. Cecchini, J.A.; Fernández, J.L.; Pallasá, M.; Cecchini, C. El proceso de transferencia en el aprendizaje y el desarrollo motor. Rev. Psicothema 2012, 24, 205-210.

47. Lesma, M.L.; Pérez-González, B.; Salinero, J.J. Relative age effect (RAE) in spanish football leage. J. Sport Health Res. 2011, 3, 35-46.

48. Noguera, L.M.; Quintero, M.V.; García, R.; Viderte, J.A. Efectos de un programa de ejercicios sobre perfil psicomotor en escolares. Revista Colomb. Rehabil. 2015, 14, 38-44. [CrossRef]

49. Vega, A. Lateralidad, Organización y Estructuración Espacial en Niños Con Dificultades; Trabajo fin de Grado; Universidad de La Rioja: Logroño, España, 2017.

50. Ferry-Rey, G.; Dueñas, J.M.; Camps, C. Diferencias entre psicomotricidad dinámica y normativa en el desarrollo infantil. Rev. Int. Med. Científica Act. Física Deporte. in press. [CrossRef]

51. Terry, J. Análisis de la Influencia de la Metodología de la Intervención Psicomotriz Sobre el Desarrollo de Las Habilidades Motrices en Niños de 3 a 4 Años. Ph.D. Thesis, Universidad de Murcia, Murcia, España, 2014.

52. Mendieta, L.; Gayrey, O.; Valverde, M.X.; Vargas, J.D. Incidencia en el juego de la rayuela en el desarrollo de la psicomotricidad. Rev. Multidiscip. Investig. Cient. Espirales 2019, 3, 1-17. [CrossRef]

(C) 2020 by the authors. Licensee MDPI, Basel, Switzerland. This article is an open access article distributed under the terms and conditions of the Creative Commons Attribution (CC BY) license (http://creativecommons.org/licenses/by/4.0/). 